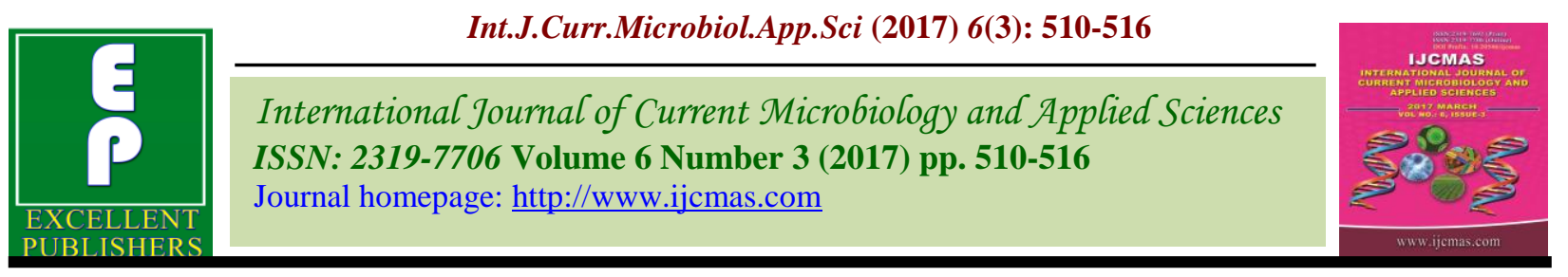

Original Research Article

https://doi.org/10.20546/ijcmas.2017.603.059

\title{
Assessment of Fungal Pathogens Associated with Spoilage of Cucumber (Cucumis sativus L.) Fruits
}

\author{
M.B. Jidda* and M.M. Muhammad \\ Department of Crop Protection, Faculty of Agriculture, University of Maiduguri, \\ Borno State, Nigeria \\ *Corresponding author
}

\begin{tabular}{|c|c|}
\hline & A B S T R A C T \\
\hline $\begin{array}{l}\text { Ke y w or d s } \\
\text { Cucumber, } \\
\text { Maiduguri, } \\
\text { Aspergillus, Yeasts, } \\
\text { Saccharomyces, } \\
\text { Zygosaccharomyces }\end{array}$ & $\begin{array}{l}\text { Cucumber (Cucumis sativus } \text { L.) fruit is cultivated for its nutritional and medicinal values. } \\
\text { It is however, lost due to deterioration resulting from fungal pathogens. This research was } \\
\text { undertaken to characterize the pathogens associated with fruit rot of cucumber collected } \\
\text { from four retail outlets located in different parts of Maiduguri Metropolis. Assessment of } \\
\text { the diseased cucumber fruits from the locations showed that Gamboru vegetable market } \\
\text { was the most heavily infested location with all the fungal isolates. Aspergillus spp. } \\
\text { constituted the highest }(48 \% \text { ) of fungal isolates from all the locations. Isolations from } \\
\text { diseased cucumber fruits recorded Zygosaccharomyces bailii (Isolation frequency = }\end{array}$ \\
\hline Article Info & \\
\hline $\begin{array}{l}\text { Accepted: } \\
\text { 10 February } 2017 \\
\text { Available Online: } \\
10 \text { March } 2017\end{array}$ & $\begin{array}{l}\text { were found to be pathogenic on cucumber fruits, with A. ustus being the most destructive, } \\
\text { followed by } S \text {. resus and Z. bailii and least pathogenic was A. niger. Rot occurring on shelf } \\
\text { reduces shelf life and market value and altogether renders fruits unfit for human } \\
\text { consumption. Careful handling of the fruits and regularly checking to remove all spoiled } \\
\text { fruits will ensure longer shelf life and prevent spread of these rot pathogens. }\end{array}$ \\
\hline
\end{tabular}

\section{Introduction}

In the northeastern part of Nigeria, cucumber (Cucumis sativus L.) is an important vegetable used to be cultivated once annually during the rainy season (June to August). It is usually planted along farm boundaries or widely scattered within the main crops (millet, maize, cowpea, groundnut, etc.) mainly by women who use the fruits as refreshments during farm activities such as weeding, harvesting, etc. or taken home to the children as gift from the farm. Older women may harvest some and sell in very small quantity. But nowadays, cucumber production has gone commercial all year round by small farm holders using irrigation.
Cucumber fruit is usually consumed raw alone or eaten with other vegetables as salad in this part of the country. It is served and eaten at home or in restaurants especially fast food establishments (Chiejina and Onaebi, 2013).

The crop is widely grown because of the nutritional and medicinal importance of the fruit. According to Vimale et al., 1999, the fruit is a veritable source of vitamins such as vitamin $\mathrm{A}, \mathrm{C}, \mathrm{K}, \mathrm{E}$, among others; minerals such as magnesium, potassium, manganese, phosphorus, calcium and zinc as well as a number of phyto-nutrients (carotene-B, 
Xanthein-B and lutein) which add and enrich the diet of people living in the tropical regions. The seed kernels are occasionally eaten (Aboloma et al., 2009). Medicinally, Cucumber gives relief to those suffering from heart burn, acid stomach, gastritis, ulcer as well as lung, stomach and chest problems (Bates et al., 1990).

Cucumber fruits grown in the field and in transit are affected by postharvest diseases leading to spoilage of the fruits. Postharvest spoilage of fruits is mainly caused by fungi. Fungi, especially moulds are important pathogens of fruits and vegetables particularly under tropical and sub-tropical conditions (Adebayo and Diyaolu, 2003). Several pathogenic fungi such as Alternaria tenuis, $A$. alternata, Aspergillus spp., Bipolaris sp., Botrytis cinerea, Cladosporium tenuissimum, C. cladosporioides, Corynespora cassiicola, Choanephora cucurbitarum, Curvulariasp. Didymella bryoniae, Fusarium equiseti, F. solani, Geotrichum candidum, Penicillium oxalicum, Phytophthora capsici and Rhizopusnigricans have been reported (van Steekelenburg, 1986; Blancard et al., 2005; Gevens et al., 2006; Naureen et al., 2009; AlSadi et al., 2011) to be associated with rots of both immature and mature cucumber fruits. It was estimated that about $20-30 \%$ of all fruits and vegetables produced is lost each year due to spoilage resulting from postharvest diseases (Kader, 2002; Agrios, 2005; Barth et al., 2009). Economic losses due to postharvest diseases may be up to $50 \%$ or even higher in developing countries (Park et al., 2008).

Cucumber fruit rot is not only a challenge to the farmers but also the vegetable and fruit vendors who will have to shelf it for sometimes in the course of selling. Rot occurring on shelf reduces shelf life and market value and altogether renders fruits unfit for human consumption. There is paucity of information on fungi associated with or responsible for spoilage of cucumber fruits in the northeastern part of Nigeria, especially, Maiduguri. The objective of the present study was to identify and determine the pathogenicity of fungi associated with spoiled cucumber fruits collected from some vegetable retail outlets in Maiduguri Metropolis, Borno State, Nigeria.

\section{Materials and Methods}

The experiment for the assessment of fungal pathogens associated with infected cucumber fruit was conducted at the Plant Pathology Laboratory, Department of Crop Protection, University of Maiduguri, Borno State, Nigeria during the months of April to June, 2015.

\section{Sample collection}

For the laboratory assessment,four different vegetable retail outlets were used for collection of the samples. Twelve (12) samples of the infected cucumber were obtained from each of the four retail outlets located at Gamboru vegetable market, Baga Motor Park, Bama Motor Park and Maiduguri Monday Market in Maiduguri Metropolis.

\section{Culturing procedure}

Each of the infected samples was washed and surface sterilized in $1 \%$ commercial bleach for one minute. These were then rinsed in three successive changes of sterile distilled water and blotted dry with sterile filter paper. From each sample, five pieces of segments measuring $3 \mathrm{~mm}^{3}$ from the advancing margins of rotted lesions and the healthy tissues were cut out with a sterile scalpel and forceps, and plated on acidified potato dextrose agar (PDA) in $90 \mathrm{~mm}$ Petri dishes. The plates were incubated at room temperature $\left(28 \pm 2^{\circ} \mathrm{C}\right)$ for seven days. 


\section{Identification of the isolated fungi}

During incubation of the plated samples, developing fungal colonies were subcultured continuously on fresh PDA plates to obtain pure cultures of the isolates. Fungal isolates were identified based on growth pattern, colour of mycelia and microscopic examinations of vegetative and reproductive structures of the fungi according to IMI, 1992; Barnett and Hunter, 1998).

\section{Pathogenicity test}

The isolated fungi were tested for their ability to induce rot in healthy cucumber fruits. Healthy samples of cucumber fruits were washed and surface sterilized with $1 \%$ commercial bleach and then washed in running tap water. The fruits were weighed before inoculation to serve as fresh weight in grammes. With the aid of a sterile cork borer, $5 \mathrm{~mm}$ diameter cylindrical holes were dug into the healthy cucumber fruits and the plugs were pulled out. In each hole, a $3 \mathrm{~mm}$ diameter mycelial disc of pure culture of each of the fungal isolates was introduced by placing it at the bottom of the hole. The plugs were carefully replaced and the wounded area sealed with sterile petroleum jelly to prevent external infection. The inoculated fruits were incubated at room temperature $\left(28 \pm 2{ }^{\circ} \mathrm{C}\right)$ for 10 days. Inoculated cucumber fruits were subsequently observed for rot development. After which, the fruits were then weighed again to get the final weight after inoculation. The degree of Pathogenicity of each fungus on the inoculated samples was determined by measuring diameter $(\mathrm{mm})$ of rotten parts and Weight loss (g).

\section{Results and Discussion}

The occurrence of fungal isolates in spoiled samples of cucumber fruits collected from four different locations in Maiduguri are presented in table 1. Isolations from the spoiled cucumber fruits collected from all the locations yielded five Aspergillus species and three yeast species. Aspergillus flavus, A. niger, Saccharomyces resus andZyggosaccharomycesbailii were isolated from the rotten cucumber fruits collected from Baga road, Bama road, Gamboru market and Monday market. While A. oryzaeand $A$. wentii were only found in cucumber samples collected from Gamboru vegetable market. Saccharomyces cerevisiae occurred in samples collected from Bama road and Gamboru market. All the fruit samples collected from Gamboru market were infected with the fungal isolates found in this study.

Table 2 shows the frequency of occurrence of fungal isolates from all the locations. The percentage occurrence of $Z$. bailii was the highest (29.2\%). A. flavusand A. niger collectively occurred in $33 \%$ of the samples collected from all the locations. While A. oryzae and A. wentii had the lowest frequency of occurrence of $2 \%$ each.

Percent occurrence of fungal isolates from the infected cucumber samples are presented in figure 1. Twenty-two percent of the diseased sample collected from different locations had Z. bailii representing the highest frequency of occurrence of the fungal isolate. This was followed by A. niger, S. cerevisiae,A. flavus, $S$. resus and $A$. ustus with 18.4, 15.3, 14.8, 12.7 , and $11.0 \%$ occurrence, respectively. While the least isolated fungi from the diseased samples were A. wentii $(3.1 \%)$ and A. oryzea $(3.0 \%)$.

Table 3 shows pathogenicity of fungal isolates on fresh cucumber fruits. All the fungal isolates have been proved to be pathogenic to cucumber fruits. The most pathogenic fungal isolate was $A$. ustus with rot diameter of $47 \mathrm{~mm}$ which resulted in the highest weight loss of $25.5 \%$. Both $S$. resus 
and Z. bailii had rot diameter of $43 \mathrm{~mm}$ each which resulted in reduction of fresh fruit weight by 23.4 and $24.8 \%$, respectively. The least pathogenic fungal isolate was A.niger with $34 \mathrm{~mm}$ rot diameter and lowest fresh fruit weight loss of $17.4 \%$.

Table.1 Occurrence of fungi isolated from spoiled cucumber fruits collected from four different locations in Maiduguri Metropolis

\begin{tabular}{|c|c|c|c|c|}
\hline \multirow{3}{*}{ Fungi } & \multicolumn{4}{|c|}{ Locations } \\
\hline & Baga & Bama & Gamboru & Monday \\
\hline & Road & Road & Market & Market \\
\hline Aspergillus flavus & + & + & + & + \\
\hline A. niger & + & + & + & + \\
\hline A. oryzae & - & - & + & - \\
\hline A. ustus & + & + & + & - \\
\hline A. wentii & - & - & + & - \\
\hline $\begin{array}{l}\text { Saccharomyces } \\
\text { cerevisiae }\end{array}$ & - & + & + & - \\
\hline S. resus & + & + & + & + \\
\hline Zygosaccharomycesbailii & + & + & + & + \\
\hline
\end{tabular}

Table.2 Percentage distribution of Fungi in different locations in Maiduguri Metropolis

\begin{tabular}{cc}
\hline Fungal isolates & \% occurrence \\
\hline A. flavus & 16.4 \\
A. niger & 16.6 \\
A. oryzae & 2.0 \\
A. ustus & 11.0 \\
A. wentii & 2.0 \\
S. cerevisae & 7.6 \\
S. resus & 15.2 \\
Z. bailli & 29.2 \\
\hline
\end{tabular}

Table.3 Pathogenicity test on fresh cucumber fruits

\begin{tabular}{lcccc}
\hline \multicolumn{1}{c}{ Fungi } & $\begin{array}{c}\text { Fresh weight } \\
\text { of sample (g) }\end{array}$ & $\begin{array}{c}\text { Final weight } \\
\text { of sample (g) }\end{array}$ & \% weight loss & $\begin{array}{c}\text { Diameter of } \\
\text { rot (mm) }\end{array}$ \\
\hline A. flavus & 116.2 & 95.6 & 17.7 & 38 \\
A. niger & 213.8 & 176.5 & 17.4 & 34 \\
A. oryzae & 262.2 & 201.3 & 23.2 & 40 \\
A. ustus & 217.5 & 162.1 & 25.5 & 47 \\
A. wentii & 227.4 & 176.3 & 22.5 & 38 \\
S. cerevisiae & 213.7 & 174.0 & 18.6 & 39 \\
S. resus & 174.4 & 133.6 & 23.4 & 43 \\
Z. bailii & 239.8 & 180.3 & 24.8 & 43 \\
\hline
\end{tabular}




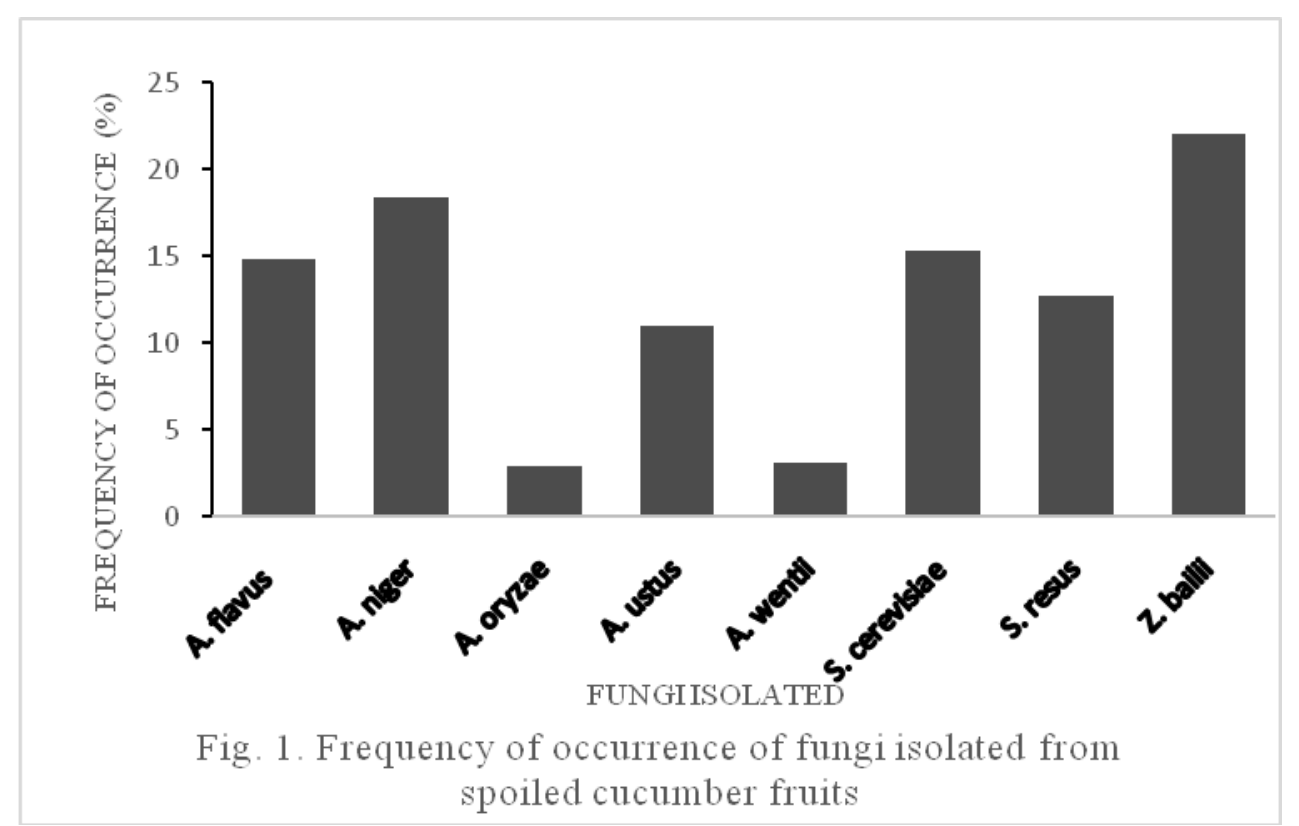

The Assessment of deteriorated cucumber fruit samples has shown that the sample locations were contaminated with five species of Aspergillus (A. flavus, A. niger, A. oryzae, A. ustus and $A$ wentii) and three species of yeast which included $S$. cerevisiae, $S$. resus and $Z$. bailii.

The most heavily infested location was Gamboru vegetable market where cucumber fruit samples from there recorded all the fungal isolates. This might not be unconnected with the market being the main vegetable market where different types of fruits and vegetables usually gather for onward distribution to other markets/shops/sales outlets. This may serve as the source of various fungal pathogens responsible for postharvest diseases of various other fruits. The least infested location was Monday market with only four out of the eight fungal isolates found from the locations. The distribution of these fungi from the locations showed that Aspergillus species constituted the most frequently (48\%) isolated fungi followed by $Z$. bailii $(29.2 \%)$ from all the locations. The least isolated fungi from the four locations were $A$. oryzae and $A$. wentii with isolation frequency of $2 \%$ each.
Yaji et al., (2016) similarly reported the presence of Aspergillus spp. in all their surveyed locations and concluded that fruits sold in all these locations were contaminated.

Isolations from diseased cucumber fruits recorded A. niger (percentage occurrence $=18.4$ ) as the most occurring fungi among Aspergillus spp., followed by A. flavus (14.8\%) and A. ustus (11.0\%). The least encountered fungi were $A$. oryzae and $A$. wentii. Rotten cucumber fruits were similarly reported (Al-Sadi et al., 2011; Chiejina and Onaebi, 2013; Yaji et al., 2016) to be host to Aspergillus species. Akinmusire (2011); Oviasogie et al., (2015); Samuel and Ifeanyi (2015) and Jidda and Benjamin (2016) found Aspergillus species as the dominant fungal isolates in tomato, orange, onions and other spoiled fruits in Nigeria.

All the Aspergillus spp. found in the present study was pathogenic to fresh cucumber fruit samples. A. ustus was the most pathogenic isolate with the highest rot diameter $(47 \mathrm{~mm})$ that led to $25 \%$ loss in fresh fruit weight. Loss in fresh fruit weight was due to loss in water content resulting from rots induced by the inoculated pathogens. The findings agreed 
with the reports of Akinmusire (2011) that Aspergillus spp. were pathogenic to all their tested fruits. Aspergillus spp. were however, found by Al-Sadi et al., (2011) to be weakly pathogenic to immature cucumber fruits.

Among the yeasts, $Z$. bailii (Isolation frequency $=22.0 \%$ ) were the most frequently isolated fungi from the diseased cucumber fruits followed byS. cerevisiae (15.3\%). Fruit deterioration was also high among the yeasts (Saccharomyces spp. and Z. bailii) inoculated samples. These yeasts were also highly pathogenic to fresh cucumber fruits with rot diameter reaching up to $43 \mathrm{~mm}$ which resulted in more than $24 \%$ loss in fresh fruit weight. $Z$. bailii has been found to be the major cause of food spoilage in many different products including fruit juices, sauces, carbonated soft drinks, and ketchup. These yeasts have a reputation of being able to grow on a very high concentration of sugars (Pitt and Hocking, 2009) and have caused significant economic losses to the food industry (Anonymous, 2016). Saccharomyces species though described as brewers' yeasts involved in the fermentation of many agricultural commodities such as millet, guinea corn, potato to make beer; the same yeasts were identified as cause of spoilage of pepper, orange mango, banana and tomato fruits (Mbajiuka et al., 2014; Ibrahim and Sada, 2015; Oviasogie et al., 2015).

In conclusion, the present study has shown that Yeasts (Saccharomyces spp and Z. bailii) as well as Aspergillus spp. were not only associated with diseased samples but were actually the cause of spoilage of cucumber fruits on the shelves of fruit sellers. These rot pathogens require predisposing conditions/factors (physiological state of the fruit, presence of wound and injury, etc.) to gain entry into the fruits to cause spoilage. Careful handling of the fruits and regularly checking to remove all spoiled fruits will ensure longer shelf life and prevent spread of these pathogens from diseased to healthy fruits either by contact and other means.

\section{References}

Aboloma, R.I., Onifade, A.K. and Adetuyi, F.C. 2009. Fungi associated with the deterioration of some fruits of the family Cucurbitaceae. Nigerian J. Mycol., 2: 229-236.

Adebayo, L.O. and Diyaolu, S.A. 2003. Mycology and spoilage of cashew nuts. African J. Biotechnol., 2: 369-373.

Agrios, G.N. 2005. Plant Pathol., Academic Press, New York. 922 pp.

Akinmusire, O.O. 2011. Fungal species associated with the spoilage of some edible fruits in Maiduguri Northern Eastern Nigeria. Adv. Environ. Biol., 5(1): 157-161.

Al-Sadi, A.M., Al-Said, F.A., Al-Kaabi, S.M., Al-Quraini, S.M., Al-Mazroui, S.S., AlMahmooli, I.H. and Deadman, M.L. 2011. Occurrence, characterization and of fruit rot of immature cucumbers under greenhouse conditions in Oman. Phytopathologia Mediterranea, 50(3): 421-429.

Anonymous. 2016. Zygosaccharomyces bailii food spoilage yeast.

Barnett, H.L. and Hunter, B.B. 1998. Illustrated genera of imperfect fungi. 4th ed. APS Press, St. Paul, Minnesota, 218pp.

Barth, M., Hankinson, T.R., Zhuang, H. and Breidt, H. 2009. Microbiological spoilage of fruits and vegetables. In Sperber, W. H. and Doyle, M. P. (Ed.), Compendium of the microbiological spoilage of foods and beverages, food microbiology and food safety, pp. 135-183. Springer Science-Business Medi, LLC.

Bates, D.M., Richard, W.R. and Jeffrey, C. 1990. Biology and utilization of the Curcurbitaceae. Cornell University Press, 52pp.

Blancard, D., Lecoq, H. and Pitrat, M. 2005. A colour atlas of cucurbit diseases: 
observation identification and control. Manson Publishing, France.

Chiejina, N.V. and Onaebi, C.N. 2013. In vitro fungicidal activity of two plant extracts against five phytopathogenic fungi of cucumber (Cucumis sativusL.) fruit. Int. J. Appl. Natural Sci., 2(3): 61-68.

Gevens, A.J., Ando, K., Lamour, K.H., Grumet, R. and Hausbeck, M.K. 2006. A detached cucumber fruit method to screen for resistance to Phytophthora capsiciand effect of fruit age on susceptibility to infection. Plant Dis., 90: 1276-1282.

Ibrahim, M. and Sada, M.D. 2015. Yeasts associated with spoilage of some selected fruits in Sokoto Metropolis. Available at http://scienceq.org/Journals/JALS.php.

Accessed 30th June, 2016.

International Mycological Institute (IMI). 1992. Descriptions of fungi and bacteria, Set 113, nos. 1121-1130.

Jidda, M.B. and Benjamin, F. 2016. Identification of fungi associated with storage bulb rot and seed of onion (Allium cepa L.) in Maiduguri, Northeastern Nigeria. Int. J. Modern Botany, 6(2): 2630.

Kader, A.A. 2002. Post-harvest technology of horticultural crops. University of California, Agriculture and Natural Resources. Pub. 3311.

Mbajiuka, S.C. and Enya, E. 2014. Isolation of microorganisms associated with deterioration of tomato (Lycopersiconesculentum) and pawpaw (Carica papaya) fruits. Int. J. Curr. Microbiol. Appl. Sci., 3(5): 501-512.

Naureen, F., Humaira, B., Viqar, S., Jehan, A. and Syed, E. 2009. Prevalence of postharvest rot of vegetables and fruits in Karachi, Pakistan. Pak. J. Botany, 41(6): 3185-3190.

Oviasogie, F.E., Ogofure, A.G., Beshiru, A., Ode, J.N. and Omeje F. I.2015. Assessment of fungal pathogens associated with orange spoilage. African J. Microbiol. Res., 9(29): 1758-1763.

Park, I., Kim, J., Lee, Y. and Shin, S. 2008. In vivo fungicidal activity of medicinal plant extracts against six phytopathogenic fungi. Int. J. Pest Management, 54(1): 6368.

Pitt, J.I., Hocking, A.D. 2009. Fungi and food spoilage, $3^{\text {rd }}$ edn. Springer, Dordrecht/ Heidelberg, 519 pp.

Samuel, O. and Ifeanyi, O. 2015. Fungi associated with the deterioration of postharvest onion bulbs sold in some markets in Awka, Nigeria. Bioengineering and Biosci., 3(5): 90-94.

van Steekelenburg N.A.M. 1986. Factors influencing internal fruit rot of cucumber caused by Didymellabryoniae. Netherland J. Plant Pathol., 92: 81-91.

Vimale, P., Ting, C.C., Salbiah, H., Ibrahim, B. and Ismail, L. 1999. Biomass production and nutrient yields of four green manures and their effects on the yield of cucumber. J. Trop. Agri. Food Sci., 27: 47-55.

Yaji, M.E., Aernan, P.T. and Sule, M. 2016. Microorganisms associated with the spoilage of cucumber, garden egg and pawpaw in Makurdi Metropolis, Benue Nigeria. Int. J. Recent Res. Life Sci., 3(1): 11-18.

\section{How to cite this article:}

Jidda, M.B. and Muhammad, M.M. 2017. Assessment of Fungal Pathogens Associated with Spoilage of Cucumber (Cucumis sativus L.) Fruits. Int.J.Curr.Microbiol.App.Sci. 6(3): 510516. doi: https://doi.org/10.20546/ijcmas.2017.603.059 